\title{
SF3B1 wt Allele
}

National Cancer Institute

\section{Source}

National Cancer Institute. SF3B1 wt Allele. NCI Thesaurus. Code C98285.

Human SF3B1 wild-type allele is located in the vicinity of 2q33.1 and is approximately 43 $\mathrm{kb}$ in length. This allele, which encodes splicing factor 3B subunit 1 protein, plays a role in the regulation of mRNA processing. 